\title{
Estimation of Microbial Biomass Carbon and Nitrogen in Bangladesh Soils
}

\author{
Jamil Haider, Takuya Marumoto*, and Abul Kalam Azad \\ Institute of Postgraduate Studies in Agriculture, Salna, Gazipur, Bangladesh; and \\ * Faculty of Agriculture, Yamaguchi University, Yamaguchi, 753 Japan
}

Received April 20, 1990

\begin{abstract}
In order to estimate the microbial biomass content and to quantify the amount of available plant nutrients derived from microbial biomass in Bangladesh soils, biomass- $C,-N$, and available- $N$ contents using samples from 8 soils were measured by applying the chloroform fumigation and drying-rewetting methods, respectively. 1) Contents of organic carbon and total nitrogen were 0.36-1.06 (av. 0.74) and 0.04-0.11 (av. 0.07)\% in samples from eight soils collected in the central and north-eastern region of Bangladesh. 2) The contribution of biomass-C to soil organic carbon was about $2 \%$, ranging from 1.35 to 3.32 . The contribution was higher in grassland soil than in cropped arable soil with similar organic $\mathrm{C}$ contents. 3) The contribution of biomass- $\mathrm{N}$ to total soil nitrogen ranged from 1.15 to 2.95 (av. 2.11). 4) The average ratio of flush-C to flush-N for a 10 day period of incubation was 7.02. 5) The contents of organic $\mathrm{C}$, microbial biomass and available plant nutrients in the Bangladesh soils were significantly lower than those in the temperate region soils where intensive agriculture is practiced.
\end{abstract}

Key Words: biomass-C, biomass-N, flush-C, flush-N, fumigation.

Populations of heterotrophic soil microorganisms play a major role in the decomposition of organic materials applied to the soil at different time intervals. These decomposed materials are used as carbon source by the microbes for the multiplication of their cell number or the increase of their population. Moreover, soil microbial biomass acts also as a sizeable reservoir for plant nutrients in soil. A part of the microbial population used to die regularly due to the changes of the environmental conditions (Marumoto et al. 1982a). These dead cells can be easily decomposed and mineralized by the microorganisms that survived (Jenkinson 1976; Anderson and Domsch 1978; Nelson et al. 1979), and they contribute a considerable amount of nutrients for the growing plants (Anderson and Domsch 1980; Marumoto et al. 1982b).

Crop productivity of soil depends mainly on its fertility status, i.e., the amount of available nutrients in soil. These available plant nutrients which reflect the soil fertility are mostly derived from the soil microbial biomass. In general, the fertility status of the Bangladesh soils is assumed to below, because the soils are not regularly amended with enough organic matter to increase their carbon and nitrogen contents (Alamgir 1975). The contents of organic carbon and total nitrogen in the Bangladesh soils are generally as follows: C: $0.4-0.7 \%$ and N: $0.04-0.07 \%$ except for some typical soils such as acid basin clay, dark grey floodplain and peat soils (C: $1.1-2.4 \%$, N: $0.12-0.21 \%$ ) (UNDP/FAO Soil Survey 
Project 1971). These $\mathrm{C}$ and $\mathrm{N}$ contents are relatively lower than those of soils for agricultural use in the temperate region (Brady 1974; Anderson and Domsch 1980). Moreover, the turnover rate of soil organic matter in tropical soils is higher compared to temperate soils, due to the favorable soil temperature and other environmental factors. However, information about soil microbial biomass is limited and few studies on the fertility status of the Bangladesh soils have been carried out.

The first objective of our studies was to estimate the microbial biomass content of different Bangladesh soils by using the chloroform-fumigation method (Jenkinson 1976; Jenkinson and Powlson 1976a, b; Jenkinson et al. 1976; Powlson and Jenkinson 1976). According to this method the size of the flush of $\mathrm{CO}_{2}$ mineralization caused by $\mathrm{CHCl}_{3}$ fumigation can be used for estimating the amount of microbial biomass in soils (Jenkinson and Powlson 1976; Anderson and Domsch 1978; Marumoto 1984).

The second objective was to quantify the amount of available plant nutrients derived from microbial biomass in these soils.

\section{MATERIALS AND METHODS}

Soils. Samples from eight soils were collected from the central and north-eastern region of Bangladesh in July-August, 1989 from paddy (upland conditions) and upland fields after harvesting of the crop. Table 1 indicates the location, series, crop productivity, and fertilizer management of these soils. They were sampled to a depth of $10 \mathrm{~cm}$ after removing the top $2-3 \mathrm{~cm}$ soil. Samples were brought to the laboratory and spread for partial air-drying after removal of the roots, insects, worms, and some small pieces of organic matter. This procedure was necessary to reduce the water content of the soils and to pass them through a $2 \mathrm{~mm}$ sieve. After sieving, the moisture content of the soils was adjusted to about $50 \%$ of max. water holding capacity (WHC) and incubated aerobically at $25^{\circ} \mathrm{C}$ in loosely closed polyethylene bags for 10 days before further treatments. Disruption of soil aggregates can kill some soil organisms as well as expose some previously inaccessible substrates to microbial attack (Powlson 1980). The purpose of this preincubation was to allow the effect of drying and sieving on soil respiration to subside (Rovira and Greacen 1957; Craswell and Waring 1972). Some characteristics of these soils are shown in Table 2.

Measurement of soil initial parameters. Soil initial parameters described in Table 2 were determined by the following methods: a) Soil $\mathrm{pH}$ was measured with a glass electrode using a $1: 2$ soil : water ratio; b) total nitrogen ( $\mathrm{T}-\mathrm{N})$ content in soil was determined by the Kjeldahl method using $\mathrm{CuSO}_{4}$ and $\mathrm{Se}$ as catalysts (Bremner 1965a); c) organic carbon (organic C) content was determined by Tyurin's (Tyurin 1980) method; and d) cation exchange capacity (CEC) of the samples was measured by Schollenberger's (Schollenberger 1980) method.

All the soils were classified according to US classification.

Soil treatments. Control samples: Preincubated moist soil samples (50\% of max. WHC) equivalent to $20 \mathrm{~g}$ dry weight were incubated in $500 \mathrm{ml}$ bottles with gas exchange plugs for $\mathrm{CO}_{2}-\mathrm{C}$ determination at $25 \pm 0.52^{\circ} \mathrm{C}$ for 10 days.

Fumigated samples: The preincubated soil samples (the same amount as controls) were fumigated with alcohol-free $\mathrm{CHCl}_{3}$ for $24 \mathrm{~h}$ in the dark in a desicattor (Jenkinson and Powlson 1976a, b) and then reinoculated with $1 \%(\mathrm{w} / \mathrm{w})$ of the respective original preincubated moist soils and incubated for 10 days by the same procedure as that described for the controls. Duplicate soil samples were used for each treatment. 
Table 1. Description of soils collected from different parts of Bangladesh, July-Aug., 1989.

\begin{tabular}{|c|c|c|c|c|}
\hline Soil & $\begin{array}{l}\text { Location } \\
\text { and } \\
\text { description }\end{array}$ & $\begin{array}{l}\text { Soil series } \\
\text { in Bangladesh }\end{array}$ & $\begin{array}{l}\text { Crop } \\
\text { productivity } \\
\text { (t/ha) }\end{array}$ & $\begin{array}{l}\text { Fertilizer } \\
\text { management } \\
(\mathrm{kg} / \mathrm{ha})\end{array}$ \\
\hline 1 & $\begin{array}{l}\text { BARI substation, Palima, Tangail, } \\
\text { river basin soil, paddy soil but } \\
\text { crops like jute also grown }\end{array}$ & Sonatola & $\begin{array}{l}\text { Rice (B.Aus.BR2) } \\
2.8 \\
\text { Jute (F. Tosha) } \\
\text { Fiber } 2.6 \\
\text { Stick } 5.7 \\
\end{array}$ & $\begin{array}{l}N: 60 \\
P: 60 \\
K: 40 \\
N: 45 \\
P: 12 \\
K: 30\end{array}$ \\
\hline 2 & $\begin{array}{l}\text { BARI substation, Palima, Tangail, } \\
\text { river basin soil, grassland soil }\end{array}$ & Sonatola & - & - \\
\hline 3 & $\begin{array}{l}\text { Bhuapur, Tangail, farmer's field, } \\
\text { river basin soil, paddy soil }\end{array}$ & N.A. $^{a}$ & $\begin{array}{l}\text { Rice (B.Aus, Hashi } \\
\text { Kalmi) } \\
1.5-2.0\end{array}$ & $\begin{array}{l}\mathrm{N}: 110 \\
\mathrm{P}: 27 \\
\mathrm{~K}: 18\end{array}$ \\
\hline 4 & $\begin{array}{l}\text { Mirzapur, Tangail, farmer's field, } \\
\text { paddy soil }\end{array}$ & N.A. & $\begin{array}{l}\text { Rice (Boro) } \\
5.6\end{array}$ & $\begin{array}{l}N: 200 \\
P: 136 \\
K: 67\end{array}$ \\
\hline 5 & $\begin{array}{l}\text { Shibpur, Narsindi, farmer's field, } \\
\text { paddy soil }\end{array}$ & Dulalpur & $\begin{array}{l}\text { Rice (IRRI) } \\
5.5\end{array}$ & $\begin{array}{l}\mathrm{N}: 70 \\
\mathrm{P}: 70 \\
\text { Oil cake: } 150 \\
\text { Cowdung: } 8.3 \mathrm{t}\end{array}$ \\
\hline 6 & $\begin{array}{l}\text { IPSA farm, Salna, Gazipur, upland } \\
\text { soil }\end{array}$ & Salna & $\begin{array}{l}\text { Rice } \\
0.5\end{array}$ & $\begin{array}{l}\mathrm{N}: 46 \\
\mathrm{P}: 46 \\
\mathrm{~K}: 22.5\end{array}$ \\
\hline 7 & $\begin{array}{l}\text { IPSA farm, Salna, Gazipur, upland } \\
\text { soil } \\
\text {. }\end{array}$ & Salna & $\begin{array}{l}\text { Wheat } \\
2\end{array}$ & $\begin{array}{l}\mathrm{N}: 120 \\
\mathrm{P}: 100 \\
\mathrm{~K}: 60 \\
\mathrm{~S}: 20 \\
\text { Compost: } 25 \mathrm{t}\end{array}$ \\
\hline 8 & $\begin{array}{l}\text { BRRI substation, Comilla, paddy } \\
\text { soil }\end{array}$ & N.A. & $\begin{array}{l}\text { Rice (Boro) } \\
5-6\end{array}$ & N.A. \\
\hline
\end{tabular}

a N.A., not available

Measurement of soil biomass carbon or flush-C. $\mathrm{CO}_{2}$ gas evolved through microbial respiration during the 10 day period of incubation was absorbed by sodatalc (Merck Co.) in two coupling U-tubes connected with an incubation bottle for $10 \mathrm{~min}$ (Marumoto 1984). The amount of $\mathrm{CO}_{2}$-C was obtained from the increment of U-tube weight according to the method described by Marumoto et al. (1974). The amount of $\mathrm{CO}_{2}-\mathrm{C}$ was measured at 3, 7, and 10 days after fumigation. Flush-C was calculated from the amount of $\mathrm{CO}_{2}-\mathrm{C}$ in the fumigated sample minus the amount of $\mathrm{CO}_{2}-\mathrm{C}$ in the unfumigated (control) sample (Powlson et al. 1987).

Measurement of soil biomass nitrogen or flush-N. After determining the amounts of $\mathrm{CO}_{2}-\mathrm{C}$, the samples of the fumigated and control soils (after 10 days of incubation) were extracted with $10 \% \mathrm{KCl}$ solution (soil : $\mathrm{KCl}$ solution $=1: 5$ ). The mineral $\mathrm{N}$ content $\left(\mathrm{NH}_{4}{ }_{-}-\right.$ $\mathrm{N}$ and $\mathrm{NO}_{3}{ }^{-}-\mathrm{N}$ ) in the $\mathrm{KCl}$ extracts of both control and fumigated samples was measured by steam distillation with $\mathrm{MgO}$ and Devarda's alloy (Bremner 1965b). Flush-N was calculated from the amount of mineralized $\mathrm{N}$ in the fumigated sample minus the amount in the control sample. 
Table 2. Characteristics of soil samples collected.

\begin{tabular}{|c|c|c|c|c|c|c|c|c|c|}
\hline Soil & Text. & $\begin{array}{l}\text { Sand } \\
(\%)\end{array}$ & $\begin{array}{l}\text { Silt } \\
(\%)\end{array}$ & $\begin{array}{l}\text { Clay } \\
(\%)\end{array}$ & $\begin{array}{l}\text { Org.-C } \\
(\%)\end{array}$ & $\begin{array}{l}\text { T-N } \\
(\%)\end{array}$ & $\mathrm{C} / \mathrm{N}$ & $\begin{array}{c}\text { CEC } \\
(\mathrm{meq} / 100 \mathrm{~g})\end{array}$ & $\mathrm{pH}\left(\mathrm{H}_{2} \mathrm{O}\right)$ \\
\hline 1 & $\mathrm{SCl}$ & 20.0 & 45.9 & 34.1 & 0.63 & 0.06 & 11.23 & 6.63 & 5.56 \\
\hline 2 & $\mathrm{CL}$ & 27.2 & 42.0 & 30.8 & 0.68 & 0.06 & 10.53 & 7.14 & 6.68 \\
\hline 3 & $\mathrm{SC}$ & 8.7 & 52.1 & 39.1 & 0.95 & 0.09 & 10.13 & 13.93 & 6.67 \\
\hline 4 & $\mathrm{CL}$ & 24.5 & 45.2 & 30.3 & 0.45 & 0.04 & 10.25 & 4.29 & 7.04 \\
\hline 5 & SCL & 17.4 & 52.1 & 30.5 & 1.06 & 0.11 & 9.60 & 8.33 & 5.71 \\
\hline 6 & $\mathrm{SC}$ & 7.6 & 41.2 & 51.2 & 0.36 & 0.04 & 10.30 & 25.58 & 6.50 \\
\hline 7 & $\mathrm{SC}$ & 8.1 & 43.6 & 48.3 & 0.74 & 0.06 & 12.30 & 17.89 & 5.47 \\
\hline 8 & $\mathrm{CL}$ & 36.6 & 23.8 & 39.6 & 1.04 & 0.11 & 9.10 & 16.43 & 5.10 \\
\hline
\end{tabular}

Table 3. Mineralization of microbial biomass-C and its contribution to total organic $\mathrm{C}$ of soil during the 10 day period of incubation after fumigation.

\begin{tabular}{cccc}
\hline Soil & $\begin{array}{c}\text { Flush-C } \\
(0-10 \text { days }) \\
(\mathrm{mg} / 100 \mathrm{~g} \text { dry soil })\end{array}$ & $\begin{array}{c}\text { Biomass-C } \\
\left(K_{\mathrm{c}}: 0.45\right) \\
(\mathrm{mg} / 100 \mathrm{~g} \text { dry soil })\end{array}$ & $\begin{array}{c}\text { Biomass-C/organic C } \\
(\%)\end{array}$ \\
\hline 1 & 3.83 & 8.51 & 1.35 \\
2 & 5.93 & 13.20 & 1.94 \\
3 & 8.60 & 19.11 & 2.01 \\
4 & 2.32 & 5.16 & 1.15 \\
5 & 11.80 & 26.22 & 2.47 \\
6 & 5.38 & 11.96 & 3.32 \\
7 & 4.91 & 10.91 & 1.47 \\
8 & 9.14 & 20.31 & 1.95 \\
\hline
\end{tabular}

Measurement of soil available $\mathbf{N}$ mineralized for 10 days after drying-rewetting treatment. After oven drying $\left(70^{\circ} \mathrm{C}, 24 \mathrm{~h}\right)$, the soil samples were reinoculated with $1 \%$ original soil, remoistened with $50 \%$ of WHC and incubated for 10 days. Mineralized N content was determined after this period by steam distillation and the amount was assumed to represent the available $\mathrm{N}$ remaining for a short period of time in soil (Marumoto 1984).

\section{RESULTS AND DISCUSSION}

\section{$\mathrm{CHCl}_{3}$-fumigation and mineralization of $\mathrm{CO}_{2}-\mathrm{C}$}

In our studies the amounts of $\mathrm{C}$ and $\mathrm{N}$ mineralized were measured during the period of incubation for up to 10 days. Jenkinson and Powlson $(1976 \mathrm{a}, \mathrm{b})$ reported that the effect of $\mathrm{CHCl}_{3}$ on rapid respiration subsided and that after 10 days there were no significant differences between the fumigated samples and the unfumigated ones. In our study all the soils showed a similar tendency except for the soil samples $1-3$. Table 3 shows the amount of mineralization of $\mathrm{CO}_{2}-\mathrm{C}$ (flush-C) and calculated biomass-C values during 10 day period of incubation after fumigation in the samples from the eight soils. The amount of flush- $\mathrm{C}$ shows a high correlation ( $r=0.90$, significant at the $1 \%$ level) with the organic $\mathrm{C}$ content of the soil (Table 2). The mineralization of $\mathrm{CO}_{2}-\mathrm{C}$ was the highest in soil 5 followed by soil 8. The lowest amount was detected in soil 4.

Soils 1 and 2, as shown in Table 1, were collected from the same location. However the amount of flush-C obtained after 10 days of incubation was clearly higher in soil 2 than in soil 1. Soil 2 was collected from a permanent grassland and soil 1 was a cropped arable soil cultivated regularly for the past 10 years, which may have reflected the higher flow of carbon 


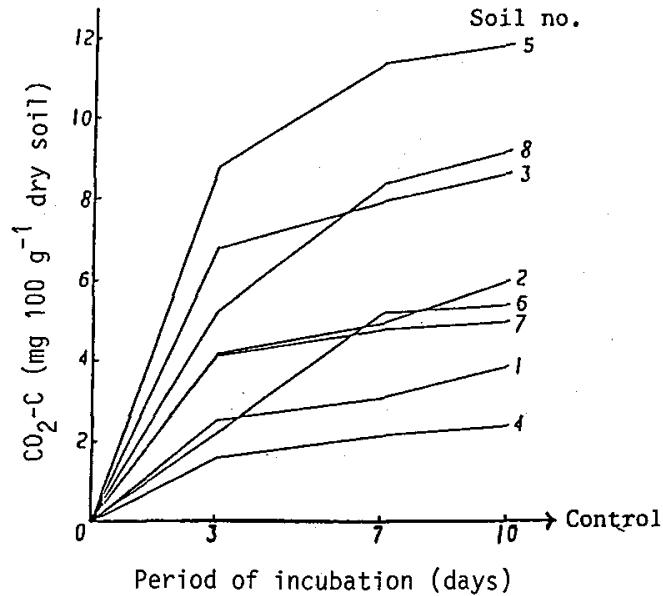

Fig. 1. Mineralization of dead biomass-C after chloroform fumigation.

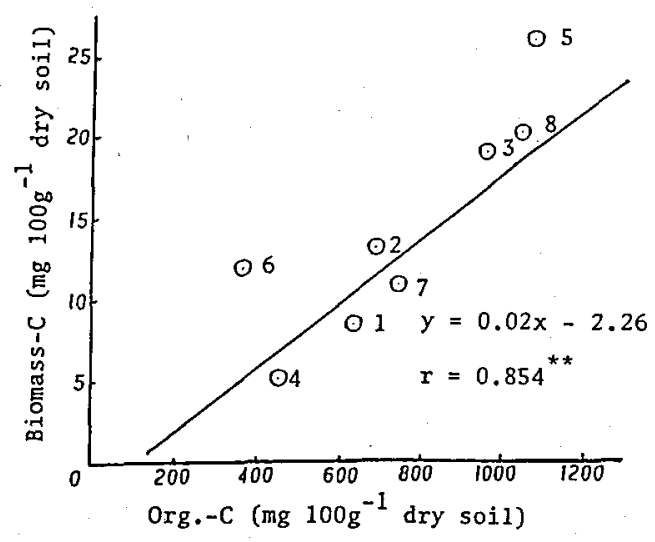

Fig. 2. Relationship between soil organic carbon content and biomass- $C$ calculated during the 10 day period of incubation. ${ }^{* *}$ Significant at $5 \%$ level. Numbers 1-8 indicate soil samples.

sources in the grassland soil than in the cropped arable soil (Jenkinson and Ladd 1981; Brookes et al. 1991).

On the other hand soils 6 and 7 were sampled from the same farm area. Soil 7 was sampled from a planned long term experimental plot, but managed with different chemical fertilizers and organic manures for one and a half year only, whereas soil 6 was collected from a plot where the top soil was completely removed and rarely cultivated. The duration of the management practices in soil 7 was clearly not sufficient to increase the microbial population, as indicated by the insufficient increase of flush-C in that soil.

Although the crop productivity of soil 4 was relatively high $(5.6 \mathrm{t} / \mathrm{ha})$, as shown in Table 1, due to the low microbial biomass content of the soil, the estimated amount of flush-C was the lowest $\left(2.32 \mathrm{mg} 100 \mathrm{~g}^{-1}\right.$ dry soil). Higher rice productivity of that soil was probably due to application of higher doses of chemical fertilizers.

Figure 1 illustrates the rapid flush of $\mathrm{CO}_{2}-\mathrm{C}$ in all the soils during the first few days of incubation. $\mathrm{CO}_{2}$ production increased up to 10 days of incubation, but the rate of increment was more rapid in the early days of incubation. A similar tendency was also reported by Jenkinson and Powlson (1976a, b).

\section{Quantity of microbial biomass in soil}

Table 3 shows the estimates of soil microbial biomass and biomass- $\mathrm{C}$ as a proportion of total organic $\mathrm{C}$ of the eight soils. To estimate the soil microbial biomass, each author has used an individual " $K_{\mathrm{c}}$ factor." In our work we used a $K_{\mathrm{c}}$ factor of 0.45 to calculate the amount of soil microbial biomass, as in the case of Oades and Jenkinson (1979) and Jenkinson and Ladd (1981). If the biomass-C content, calculated from flush-C, is compared with the soil organic carbon content (Table 2), it can be seen that biomass- $\mathrm{C}$ differs in the same manner as organic $C$ of soil does. Marumoto (1984) also observed that the amount of biomass- $C$ increased with the increase of soil organic $C$ content.

The contribution of biomass- $\mathrm{C}$ to soil organic $\mathrm{C}$ was about $2 \%$ in the soils investigated, ranging from 1.35 to 3.32 . Although the contents of organic $\mathrm{C}$ and total $\mathrm{N}$ in the soil samples were lower than those of soils for agricultural use in the temperate zone, the contribution was almost the same as that reported by Powlson et al. (1987), which indicates that the 
content of biomass- $\mathrm{C}$ in soil organic $\mathrm{C}$ varies within a definite proportion. The biomass- $\mathrm{C}$ in soils with higher clay content accounts for between 2 to $4 \%$ of the total soil organic $\mathrm{C}$ (Powlson and Jenkinson 1976; Brookes et al. 1984), which could be observed in soil 6 with more than $51 \%$ clay content. The biomass-C in this soil accounted for more than $3 \%$ of the total soil organic C. Soil 7 , on the other hand, did not show a similar biomass content, although the texture of this soil was identical with that of soil 6 . This phenomenon may be due to the increase in the organic $\mathrm{C}$ content in soil 7 , which was subjected to the application of several organic manures and fertilizers for the past one and a half years.

\section{Relationship between soil organic carbon and biomass carbon}

The relationship between the soil organic $C$ content $(x)$ and the biomass-C during the 10 day period of incubation $(y)$ in the eight soils was as follows: $y=0.02 x-2.26(r=0.85$, significant at the $5 \%$ level) as shown in Fig. 2. Biomass-C, which was calculated from the flush-C during the 10 day period of incubation, showed a similar tendency to that of the organic-C contents in the soils. Powlson and Jenkinson (1976) reported the occurrence of $\mathrm{CO}_{2}-\mathrm{C}$ flush in the following order: grassland soil $>$ cropped arable soil. This tendency also could be observed in soils 1 and 2 . Although soils 1 and 2 showed similar organic $\mathrm{C}$ contents $(0.63 \%$ in soil 1 and $0.68 \%$ in soil 2$)$, the $\mathrm{CO}_{2}-\mathrm{C}$ flush was more than 1.5 times higher in soil 2 (grassland soil) than in soil 1 (cropped arable soil). This phenomenon indicates that the supply of organic matter from the roots is generally larger in grassland soil than in cropped arable soil (Jenkinson and Ladd 1981). Furthermore, the ratio of biomass-C to organic $C$ was higher in soil 6 than in soil 7 in spite of the presence of similar amounts of biomass-C in both soils. This difference may be ascribed to the high content of organic $\mathrm{C}$ in soil 7 which was affected by the application of compost with a high $\mathrm{C} / \mathrm{N}$ ratio of residual straw.

\section{Mineralization of microbial biomass- $\mathrm{N}$ as influenced by fumigation}

The total amount of $\mathrm{N}$ mineralized from the dead microbial biomass during the 10 day

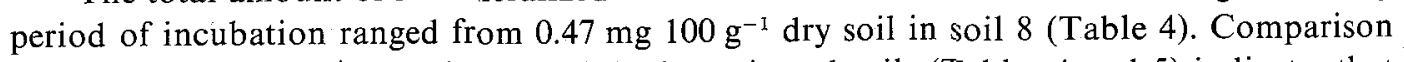
of the flush- $\mathrm{N}$ and $\mathrm{C} / \mathrm{N}$ of biomass of the investigated soils (Tables 4 and 5) indicates that in soil 2 the $\mathrm{C} / \mathrm{N}$ ratio of biomass was higher compared to the relatively lower flush- $\mathrm{N}$ value. A portion of the nitrogen released after fumigation in the grassland soil 2 may be reimmobilized into the microbes which survived during the incubation period.

For the calculation of biomass- $\mathrm{N}$, the following equation is usually considered (Brookes et al. 1985): $B_{\mathrm{N}}=F_{\mathrm{N}} / K_{\mathrm{N}}$, where $B_{\mathrm{N}}$ is the soil biomass-N, $F_{\mathrm{N}}$ is the amount of N

Table 4. Mineralization of microbial biomass-N and its contribution to total nitrogen of soil during the 10 day period of incubation after fumigation.

\begin{tabular}{cccc}
\hline Soil & $\begin{array}{c}\text { Flush-N } \\
(0-10 \text { days }) \\
(\mathrm{mg} / 100 \mathrm{~g} \text { dry soil })\end{array}$ & $\begin{array}{c}\text { Biomass-N } \\
\left(K_{\mathrm{N}}: 0.68\right) \\
(\mathrm{mg} / 100 \mathrm{~g} \text { dry soil })\end{array}$ & $\begin{array}{c}\text { Bomass-N/total } \mathrm{N} \\
\text { of soil (\%) }\end{array}$ \\
\hline 1 & 0.85 & 1.25 & 2.08 \\
2 & 0.47 & 0.69 & 1.15 \\
3 & 1.04 & 1.52 & 1.69 \\
4 & 0.80 & 1.18 & 2.95 \\
5 & 1.17 & 1.72 & 1.56 \\
6 & 0.68 & 1.00 & 2.50 \\
7 & 1.00 & 1.47 & 2.45 \\
8 & 1.88 & 2.77 & 2.52 \\
\hline
\end{tabular}


Table 5. Ratio of flush-C to flush-N and biomass-C

to biomass-N during the 10 day period of incubation after fumigation.

\begin{tabular}{ccc}
\hline Soil & Flush-C/flush-N & Biomass-C/biomass-N \\
\hline 1 & 4.51 & 6.81 \\
2 & 12.62 & 19.13 \\
3 & 8.30 & 12.57 \\
4 & 2.89 & 4.37 \\
5 & 10.09 & 15.24 \\
6 & 7.95 & 11.96 \\
7 & 4.91 & 7.42 \\
8 & 4.85 & 7.33 \\
\hline
\end{tabular}

mineralized from the dead biomass, and $K_{\mathrm{N}}$ is the fraction of biomass-N mineralized, measured under standard conditions. Values for the $K_{\mathrm{N}}$ factor ranging from 0.25 (Paul and Juma 1981) to 0.63 (Amato and Ladd 1980) have been used so far for calculating the microbial biomass- $\mathrm{N}$. Value taken as 0.25 resulted in an extremely low $\mathrm{C} / \mathrm{N}$ ratio ranging between 2.1 and 3.0 for the biomass (Schnurer et al. 1985). For this reason, some authors presented their data not on a biomass- $\mathrm{N}$ basis, but they analyzed the flush of nitrogen after fumigation (Ross et al. 1980; Adams and Laughlin 1981). Factors like microbial immobilization etc. can influence the $K_{\mathrm{N}}$ value and make it difficult to estimate. In spite of these short comings we adopted the value of 0.68 for $K_{\mathrm{N}}$, which was used by Brookes et al. (1985) and Powlson et al. (1987). Table 4 shows the calculated biomass- $N$ values of the eight different Bangladesh soils, which ranged from 0.69 to $2.77 \mathrm{mg} 100 \mathrm{~g}^{-1}$ dry soil. Biomass nitrogen content of soil 2 was extremely low due to the immobilization, as already stated.

Table 4 also shows that the contribution of biomass-N $\left(B_{\mathrm{N}}\right)$ to the total nitrogen content of the soil ranged from 1.15 to $2.95 \%$ for the different soils. In spite of the low contents of total $\mathrm{N}$ in the soil samples, the average value of 2.11 was similar to that obtained by Brookes et al. (1985) and Powlson et al: (1987).

By adopting the values of 0.45 and 0.68 , respectively, for the $K_{\mathrm{c}}$ and $K_{\mathrm{N}}$ factors, we calculated the $\mathrm{C} / \mathrm{N}$ ratio of the microbial biomass which ranged from 4.37 to 19.13 (Table 5). The average ratio was about 10, which was similar to that reported by Marumoto (1984).

\section{Relationship between carbon and nitrogen mineralized from killed microbial biomass for 10 days}

The ratio of mineralized carbon (flush-C) and nitrogen (flush-N) which is presented in Table 5 varied considerably, ranging from 2.89 to 12.62 due to the heterogeneity of the samples collected and their management practices. However, the average value of 7.02 was recorded, which agrees with the data (5.8 to 7.3 for a 10 day period of incubation) from Powlson and Jenkinson (1976).

\section{Contribution of biomass- $\mathrm{N}$ to crop productivity of collected soils in Bangladesh}

Comparison of the crop productivity (Table 1) and biomass-N (Table 4) of the collected soil samples, it indicates that the production of rice and other crops was closely related to the biomass-N content of those soils. Other factors like chemical and organic fertilizer management had also influenced the crop productivity, as observed in soil 4 . However, crop productivity depends mainly on the amount of available nutrients in soil, especially on the nutrients in the microbial biomass (Anderson and Domsch 1980; Jenkinson and Ladd 1981; 


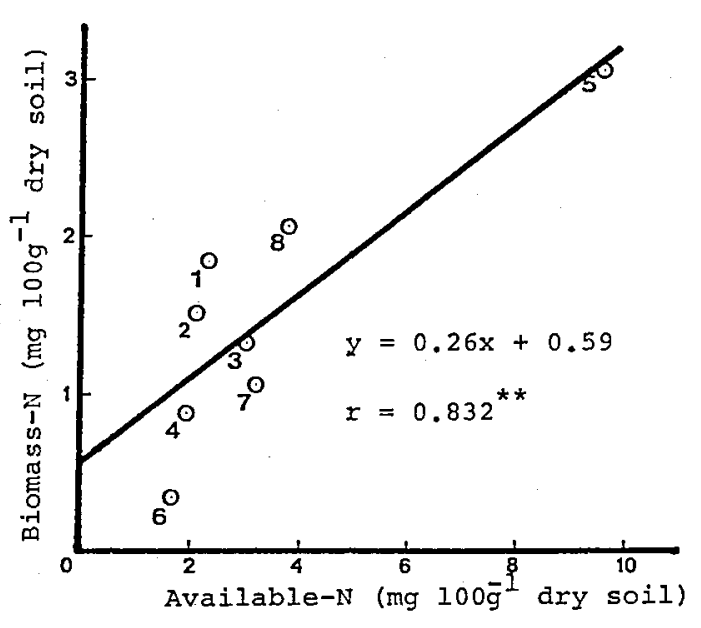

Fig. 3. Relationship between biomass-N obtained by fumigation method and available- $\mathrm{N}$ by ovendrying method for a 10 day period of incubation. ** Significant at $5 \%$ level. Numbers $1-8$ indicate soil samples.

\section{Marumoto et al. 1982b).}

The correlation between the biomass- $\mathrm{N}$ calculated by the fumigation method and available $\mathrm{N}$ by the oven drying-rewetting method for a 10 day period of incubation was significantly high $(r=0.83$, significant at the 5\% level) for all the samples (Fig. 3). Percentages of biomass- $\mathrm{N}$ to available- $\mathrm{N}$ were nearly $30 \%$. This proportion of biomass-N in the Bangladesh soils was relativaly lower than that recorded in Europe and Japan (55-77\%) (Marumoto 1984). Furthermore, the amounts of biomass-N per unit area in the Bangladesh soils were calculated from the data in Table 4. The amount of biomass-N ranged from 6.9 to $27.7 \mathrm{~kg} \mathrm{ha}^{-1}$ (mean: $14.5 \mathrm{~kg} \mathrm{~N} \mathrm{ha}^{-1}$ ). Based on the analysis of 26 agricultural soils, Anderson and Domsch (1980) stated that the average quantities of $\mathrm{C}$ and $\mathrm{N}$ in the soil microbial biomass were about 720 and $108 \mathrm{~kg} \mathrm{ha}^{-1}$, respectively. The ratio of biomass- $\mathrm{N}$ in Bangladesh soils to German soils was about $1: 7.5$. Based on this information and our results, the contents of organic $\mathrm{C}$, microbial biomass and available plant nutrients in the Bangladesh soils were significantly lower than those in the temperate region soils where intensive agriculture is practiced.

Acknowledgments. We thank Mr. A.J.M.S. Karim for the physical analysis of the soils.

\section{REFERENCES}

Adams, T.McM. and Laughlin, R.J. 1981: The effects of agronomy on the carbon and nitrogen in the soil biomass. J. Agr. Sci., 97, 319-327

Alamgir, M. 1975: Some aspects of Bangladesh agriculture. Review of performance evaluation of policies. In Bangladesh Development Studies, Vol. VIII, Dhaka

Anderson, J.P.E. and Domsch, K.H. 1978: Mineralization of bacteria and fungi in chloroform fumigated soils. Soil Biol. Biochem., 10, 207-213

Anderson, J.P.E. and Domsch, K.H. 1980: Quantities of plant nutrients in the microbial biomass of selected soils. Soil Sci., 130, 211-21.6

Brady, N.C. 1974: The Nature and Properties of Soils, p. 154-163, Macmillan Publishing Co., Inc, New York Bremner, J.M. 1965a: Total nitrogen. In Methods of Soil Analysis, Vol. 2, Ed. C.A. Black, p. 1149-1178, American Society of Agronomy, Madison

Bremner, J.M. 1965b: Inorganic forms of nitrogen. In Methods of Soil Analysis, Vol. 2, Ed. C.A. Black, p. 1179-1237, American Society of Agronomy, Madison

Brookes, P.C., Inubushi, K., Wu, J., and Patra, D.D. 1991: Properties of the soil microbial biomass. Jpn. J. 
Soil Sci. Plant Nutr., 62, 79-83 (in Japanese)

Brookes, P.C., Landman, A., Pruden, G., and Jenkinson, D.S. 1985: Chloroform fumigation and the release of soil nitrogen. A rapid direct extraction method to measure microbial biomass nitrogen in soil. Soil Biol. Biochem., 17, 837-840

Brookes, P.C., Powlson, D.S., and Jenkinson, D.S. 1984: Phosphorus in the soil microbial biomass. Soil Biol. Biochem., 16, 169-175

Craswell, E.T. and Waring, S.A. 1972: Effect of grinding on the decomposition of organic matter II. Oxygen uptake and nitrogen mineralization in virgin and cultivated cracking clay soils. Soil Biol. Biochem., 4 , 435-442

Jenkinson, D.S. 1976: The effects of biocidal treatments on metabolism in soil. IV. The decomposition of fumigated organisms in soil. Soil Biol. Biochem., 8, 203-208

Jenkinson, D.S. and Ladd, J.N. 1981: Microbial biomass in soil. Measurement and turnover. In Soil Biochemistry, Vol. 5, Ed. E.A. Paul and J.N. Ladd, p. 415-471, Dekker, New York

Jenkinson, D.S. and Powlson, D.S. 1976a: The effects of biocidal treatments on metabolism in soil I. Fumigation with chloroform. Soil Biol. Biochem., 8, 167-177

Jenkinson, D.S. and Powlson, D.S. 1976b: The effects of biocidal treatments on metabolism in soil V. A method for measuring soil biomass. Soil Biol. Biochem., 8, 209-213

Jenkinson, D.S., Powlson, D.S., and Wedderburn, R.W.M. 1976: The effects of biocidal treatments on metabolism in soil III. The relationship between soil bio-volume, measured by optical microscopy, and the flush of decomposition caused by fumigation. Soil Biol. Biochem., 8, 189-202

Marumoto, T. 1984: Mineralization of $\mathrm{C}$ and $\mathrm{N}$ from microbial biomass in paddy soil. Plant Soil, 76, 165173

Marumoto, T., Anderson, J.P.E., and Domsch, K.H. 1982a: Decomposition of ${ }^{14} \mathrm{C}-$ and ${ }^{15}$ N-labeled microbial cells in soil. Soil Biol. Biochem., 14, 461-467

Marumoto, T., Anderson, J.P.E., and Domsch, K.H. 1982b: Mineralization of nutrients from soil microbial biomass. Soil Biol. Biochem., 14, 469-475

Marumoto, T., Kai, H., Yoshida, T., and Harada, T. 1974: Contribution of microbial cells and cell walls to an accumulation of the soil organic matter becoming decomposable due to the dry of soil (part 3 ). $J$. Sci. Soil Manure, Jpn., 45, 332-345 (in Japanese)

Nelson, D.W., Martin, J.P., and Ervin, J.O. 1979: Decomposition of microbial cells and components in soil and their stabilization through complexing with model humic acid-type phenolic polymers. Soil Sci. Soc. Am. J., 43, 84-88

Oades, J.M. and Jenkinson, D.S. 1979: Adenosine triphosphate content of the soil microbial biomass. Soil Biol. Biochem., 11, 201-204

Powlson, D.S. 1980: The effects of grinding on microbial and non-microbial organic matter in soil. $J$. Soil Sci., 31, 77-85

Powlson, D.S., Brookes, P.C., and Christensen, B.T. 1987: Measurement of soil microbial biomass provides an early indication of changes in total soil organic matter due to straw incorporation. Soil Biol. Biochem., 19, 159-164

Powlson, D.S. and Jenkinson, D.S. 1976: The effect of biocidal treatments on metabolism in soil. II. Gamma irradiation, autoclaving, air-drying and fumigation. Soil Biol. Biochem., 8, 179-188

Ross, D.J., Tate, K.R., Cairns, A., and Pansier, E.A. 1980: Microbial biomass estimations in soils from tussock grasslands by three biochemical procedures. Soil Biol. Biochem., 12, 375-383

Rovira, A.D. and Greacen, E.L. 1957: The effect of aggregate disruption on the activity of microorganisms in the soil. Aust. J. Agr. Res., 8, 659-673

Schnurer, J., Clarholm, M., and Rosswall, T. 1985: Microbial biomass and activity in an agricultural soil with different organic matter contents. Soil Biol. Biochem., 17, 611-618

Schollenberger, C.J. 1980: Semimicro Schollenberger's Method. In Analytical Methods of Nutrients in Soil, Ed. Committee of the Analytical Methods of Nutrients in Soil, Japanese Society of Soil Sci. Plant Nutr., p. 34-41, Yokendo Co., Tokyo (in Japanese)

Tyurin, I.V. 1980: Tyurin's Method. In Analytical Methods of Nutrients in Soil, Ed. Committee of the Analytical Methods of Nutrients in Soil, Japanese Society of Soil Sci. Plant Nutr., p. 120-124, Yokendo Co., Tokyo (in Japanese)

UNDP/FAO Soil Survey Project Ed. 1971: Bangladesh Soil Resources, Technical Report 3, UNDP/FAO, Rome 